\title{
PPP2R1B wt Allele
}

National Cancer Institute

\section{Source}

National Cancer Institute. PPP2R1B wt Allele. NCI Thesaurus. Code C49437.

Human PPP2R1B wild-type allele is located in the vicinity of $11 \mathrm{q} 23.2$ and is approximately $40 \mathrm{~kb}$ in length. This allele, which encodes serine/threonine-protein phosphatase 2A 65 $\mathrm{kDa}$ regulatory subunit $\mathrm{A}$ beta isoform protein, plays a role in coordinating the assembly of the protein phosphatase 2A heterodimer. Functional PPP2R1B gene polymorphisms are associated with lung cancer. 